\title{
Magnetic Resonance Imaging in Delayed Carbon Monoxide Leukoencephalopathy: Diffusion and Spectroscopy Findings
}

Gecikmiş Karbonmonoksit Lökoensefalopatisinde Manyetik Rezonans Görüntüleme: Difüzyon ve Spektroskopi Bulguları

Özlem Kayım Yıldız¹, Bülent Yıldız², Selim Polat ${ }^{1}$, Şeyda Figül Gökçe1, Aslı Bolayır ${ }^{1}$, Burhanettin Çiğdem¹

${ }^{1}$ Cumhuriyet University Faculty of Medicine, Department of Neurology, Sivas, Turkey

${ }^{2}$ Cumhuriyet University Faculty of Medicine, Department of Radiology, Sivas, Turkey

Keywords: Carbon monoxide intoxication, leukoencephalopathy, magnetic resonance imaging

Anahtar Kelimeler: Karbonmonoksit intoksikasyonu, lökoensefalopati, manyetik rezonans görüntüleme

\section{Dear Editor,}

A 68-year-old male with type 2 diabetes mellitus admitted to hospital with disorientation, incomprehensible speech, behavioral disturbances, and slowing in movements, which presented 20 days after exposure to carbon monoxide $(\mathrm{CO})$, causing transient loss of consciousness. His eyes were open spontaneously, he had mutism and severe rigidity in all extremities. The carboxyhemoglobin level was normal in serum. Electroencephalography showed generalized background slowing. Cranial magnetic resonance imaging (MRI) showed diffusion restriction in the subcortical white matter and especially in the bilateral frontal lobes, which were consistent with cytotoxic edema (Figure 1A, 1B). Fluid attenuation inversion recovery (FLAIR) weighted imaging showed no marked signal changes in these areas (Figure 1C). The rigidity was significantly improved with bromocriptine treatment. Cranial MRI repeated one week later showed increased diffusion restriction in the white matter and signal changes in FLAIR-weighted imaging (Figure 2A, 2B, 2C). MR spectroscopy (MRS) showed an increase in the choline peak, a decrease in the $\mathrm{N}$-acetylaspartate (NAA) peak, and a lactate peak (Figure 3). His state of consciousness evolved into a minimally conscious state and did not improve.

Delayed leukoencephalopathy is a rare complication of hypoxic ischemic events, most commonly CO intoxication (1). A biphasic clinical pattern is commonly observed, which consists of full improvement of the initially developed consciousness disturbance, and occurrence of progressive neuropsychiatric deterioration following an interval of 2-40 days (1).

The globus pallidus and cerebral white matter are the most frequently affected areas (2). Cranial MRI reveals hyperintense lesions in T2 and FLAIR-weighted imaging, showing confluence without contrast enhancement and a mass effect in the periventricular white matter and centrum semiovale (2). Diffusion restriction without changes in other MRI sequences, as we reported in our patient, is rarely reported in the acute phase $(3,4)$. Persistence of diffusion restriction in the chronic phase suggests progressive demyelination with cytotoxic edema (2). MRS findings such as a lactate peak, increased choline peak, and decreased NAA peak have been reported (2). A lactate peak, which indicates irreversible damage, is related with akinetic mutism (2).

As a result, addition of diffusion-weighted images and MRS to conventional MRI sequences can speed up the diagnosis of delayed CO leukoencephalopathy, can make its diagnosis easier, and is important for prognostication.

Ethics

Informed Consent: Not needed.

Peer-review: Internally peer-reviewed.

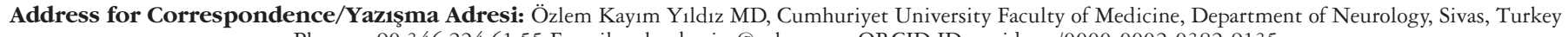
Phone: +90 3462246155 E-mail: ozlemkayim@yahoo.com ORCID ID: orcid.org/0000-0002-0382-9135

Received/Geliş Tarihi: 09.03.2017 Accepted/Kabul Tarihi: 22.03.2017

${ }^{\circ}$ Copyright 2017 by Turkish Neurological Society

Turkish Journal of Neurology published by Galenos Publishing House. 

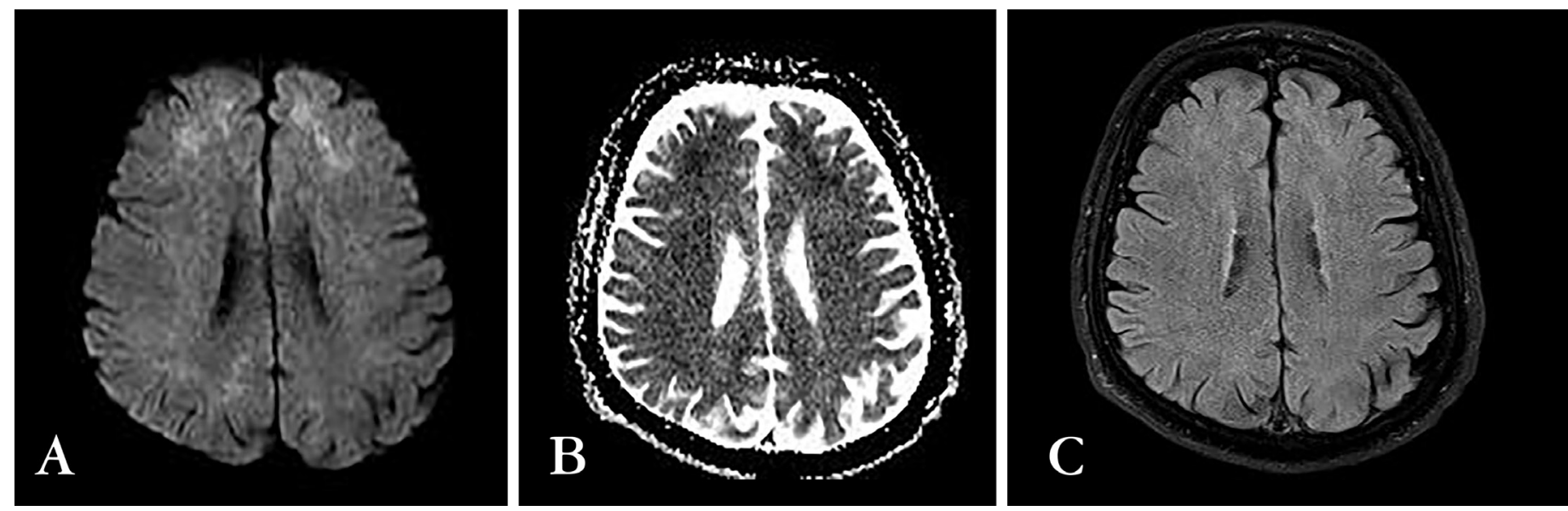

Figure 1. Axial-weighted cranial magnetic resonance imaging. A) Diffusion-weighted images: Hyperintensity in the white matter of the bilateral frontal lobes. B) Apparent diffusion coefficient: Hypointensity in the white matter of the bilateral frontal lobes (diffusion restriction). C) FLAIR: No marked signal change was observed.
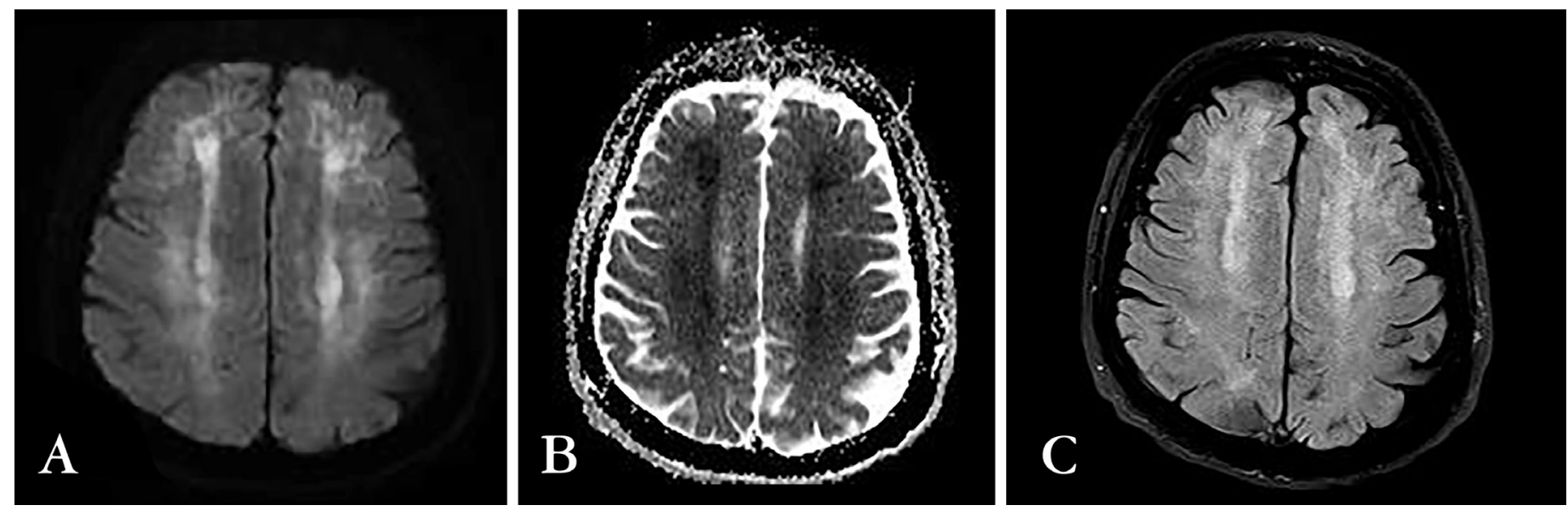

Figure 2. Axial weighted cranial magnetic resonance imaging. A) Diffusion-weighted images: Hyperintensity in subcortical white matter. B) Apparent diffusion coefficient: Hypointensity in the subcortical white matter (diffusion restriction). C) FLAIR: Hyperintensity in the subcortical white matter

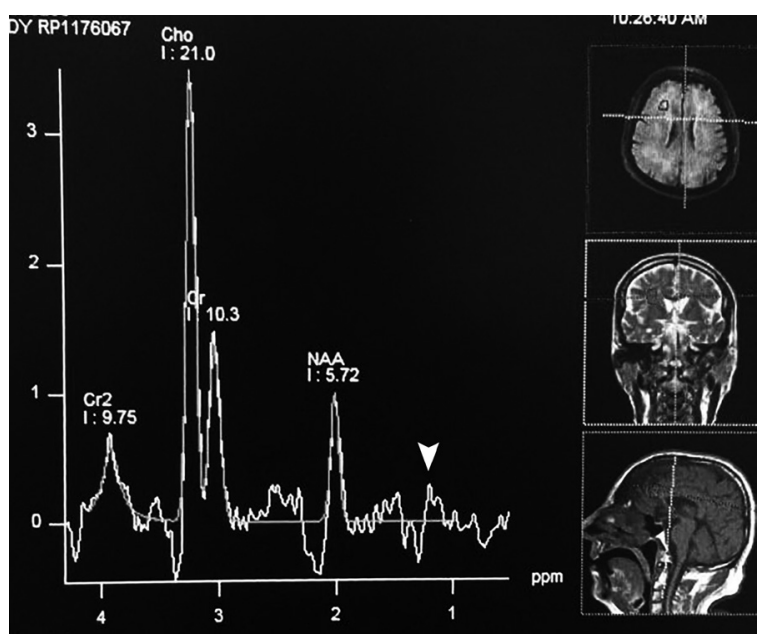

Figure 3. Increase in choline peak, decrease in $\mathrm{N}$-acetylaspartate peak, and a lactate peak (arrow) in magnetic resonance spectroscopy.

NAA: N-acetylaspartate

\section{Authorship Contributions}

Surgical and Medical Practices: Ö.K.Y., S.P., Ş.F.G., Concept: A.B., B.Ç., Ş.F.G., Design: Ö.K.Y., Data Collection or Processing: B.Y., Analysis or Interpretation: Ö.K.Y., Literature Search: Ö.K.Y., Writing: Ö.K.Y.

Conflict of Interest: No conflict of interest was declared by the authors.

Financial Disclosure: The authors declared that this study received no financial support.

\section{References}

1. Shprecher D, Mehta L. The syndrome of delayed post-hypoxic leukoencephalopathy. Neuro Rehabilitation 2010;26:65-72.

2. Beppu $\mathrm{T}$. The role of MR imaging in assessment of brain damage from carbon monoxide poisoning: a review of the literature. AJNR Am J Neuroradiol 2014;35:625-631.

3. Teksam M, Casey SO, Michel E, Liu H, Truwit CL. Diffusion-weighted MR imaging findings in carbon monoxide poisoning. Neuroradiology 2002;44:109-113.

4. Sener RN. Acute carbon monoxide poisoning: diffusion MR imaging findings. AJNR Am J Neuroradiol 2003;24:1475-1477. 